\title{
L-Ascorbic Acid Inhibits Breast Cancer Growth by Inducing IRE/JNK/CHOP-Related Endoplasmic Reticulum Stress-Mediated p62/SQSTM1 Accumulation in the Nucleus
}

\author{
Youn Kyung Choi ${ }^{1}{ }^{\mathbb{D}}$, Jung-Il Kang ${ }^{1}$, Sanghoon Han ${ }^{1}$, Young Ree Kim ${ }^{1}$, Jaemin Jo ${ }^{1}$, \\ Yong Woo Kang ${ }^{1}$, Do Ryeon Choo ${ }^{1}$, Jin Won Hyun ${ }^{1,2} \mathbb{D}$, Young Sang Koh ${ }^{1,2}$, Eun-Sook Yoo ${ }^{1,2}$ \\ and Hee-Kyoung Kang 1,2,* \\ 1 Department of Medicine, School of Medicine, Jeju National University 102 Jejudaehakno, Jeju 63243, Korea; \\ choiyk@jejunu.ac.kr (Y.K.C.); jikang0024@jejunu.ac.kr (J.-I.K.); hanimh@jejunu.ac.kr (S.H.); \\ namu8790@jejunu.ac.kr (Y.R.K.); jaemin2s@daum.net (J.J.); ky3204@gmail.com (Y.W.K.); \\ kiper3012@nate.com (D.R.C.); jinwonh@jejunu.ac.kr (J.W.H.); yskoh7@jejunu.ac.kr (Y.S.K.); \\ eunsyoo@jejunu.ac.kr (E.-S.Y.) \\ 2 Jeju Research Center for Natural Medicine, Jeju National University; 102 Jejudaehakno, Jeju 63243, Korea \\ * Correspondence: pharmkhk@jejunu.ac.kr; Tel.:+82-10-6214-5464
}

Received: 6 April 2020; Accepted: 2 May 2020; Published: 8 May 2020

check for updates

\begin{abstract}
Anticancer effects of L-ascorbic acid (Vitamin C, L-AA) have been reported in various types of cancers. L-AA intake reduces breast cancer recurrence and mortality; however, the role of L-AA in the treatment of breast cancer remains poorly understood. In this study, we investigated the effect and mechanism action of L-AA on breast cancer growth. L-AA inhibited the growth of breast cancer cells by inducing apoptotic cell death at the evaluated treatment concentrations without affecting normal cells. Moreover, L-AA induces autophagosome formation via regulation of mammalian target of rapamycin (mTOR), Beclin1, and autophagy-related genes (ATGs) and increased autophagic flux. Notably, we observed that L-AA increased p62/SQSTM1 (sequestosome 1) protein levels. Accumulation of p62 protein in cancer cells in response to stress has been reported, but its role in cancer regulation remains controversial. Here, we demonstrated that L-AA-induced p62 accumulation is related to L-AA-induced breast cancer growth inhibition. Furthermore, L-AA induced endoplasmic reticulum (ER) stress via the IRE-JNK-CHOP (inositol-requiring endonuclease-c-Jun $\mathrm{N}$-terminal kinase-C/EBP homologous protein) signaling pathways, which increased the nuclear levels of p62/SQSTM1. These findings provide evidence that L-AA-induced ER stress could be crucial for p62 accumulation-dependent cell death, and L-AA can be useful in breast cancer treatment.
\end{abstract}

Keywords: L-ascorbic acid; breast cancer; autophagy; ER stress; p62/SQSTM1; IRE-JNK-CHOP signaling

\section{Introduction}

L-ascorbic acid (Vitamin C, L-AA) is an essential micronutrient that functions as a cofactor in various enzymatic reactions [1,2]. It is a known anti-oxidant [3] and is necessary for collagen formation [4], absorption and metabolism of metal ions such as iron and copper [5], and synthesis of neurotransmitters [6]. As L-AA plays an important role in human physiology, research on the relationship between L-AA and disease is still ongoing. L-AA has been effective in the treatment of oral diseases [7], cardiovascular diseases [8], iron deficiency anemia [9], diabetes [10], age-related eye disease [11], Alzheimer's disease [12], and viral infections [13]. Moreover, L-AA inhibits the growth and metastasis of various types of cancers, including melanoma [14], breast cancer [15], gastric cancer [16], 
colorectal cancer [17], pancreatic cancer [18], and leukemia [19]. Many studies have reported that the L-AA concentration in the plasma of cancer patients $(10 \sim 30 \mu \mathrm{M})$ is lower than that of healthy controls $(50 \sim 100 \mu \mathrm{M})$ [20-24]. In adults, the recommended daily dose of L-AA is about 75-90 mg in USA [25], but administration of high-dose L-AA ( $8 \mathrm{~g} /$ day) is known to be effective in preventing common cold [26]. However, high-dose L-AA is controversial as a chemotherapeutic agent in patients with cancer [27]. Several previous studies have reported that administration of a daily dose of $10 \mathrm{~g}$ L-AA has a beneficial effect in patients with cancer [28-31], while some have reported no overall relationship with L-AA intake [32-34]. Regarding this controversy, several reports have noted that the administration route of high-dose of L-AA (oral or intravenous injection) is crucial [35]. Intravenous injections of L-AA are maintained at high level in the blood [36,37]. Based on this, it has been reported that L-AA is more effective in intravenous injection than in oral administration in cancer [38]. Therefore, well-designed clinical studies and more basic investigations are needed to validate L-AA as an effective treatment for patients with cancer.

On the other hand, endoplasmic reticulum (ER) stress is reportedly associated with the pathogenesis of various diseases such as, neurodegenerative diseases, inflammatory diseases, metabolic diseases, stroke, heart diseases, pulmonary fibrosis, and cancers [39-42]. When ER stress occurs, the unfolded protein response (UPR) is induced to protect cells from the issue of protein folding in the ER through the activation of the intracellular signaling pathway [43]. Therefore, the regulation of ER stress and UPR has been widely used as a therapeutic target for various diseases. If severe and prolonged ER stress is maintained in cancer, ER stress-mediated UPR induces the death mechanism of cancer cells [44]. Accordingly, ER stress inducers are favored as potential anticancer agents [45-47].

Breast cancer is the most common cancer among women, with the second-highest mortality rate after lung cancer [48]. Therefore, to treat patients with breast cancer, it is essential to uncover drugs that have superior efficacy with fewer side effects. Many epidemiological studies have reported that L-AA intake reduces breast cancer recurrence and mortality [49-54]. However, there is still a lack of understanding regarding the role of L-AA in the treatment of breast cancer. In this study, we investigated the effect of L-AA on the growth of breast cancer cells through ER stress-mediated pathways.

\section{Materials and Methods}

\subsection{Material}

L-AA and hydrogen peroxide $\left(\mathrm{H}_{2} \mathrm{O}_{2}\right)$ were purchased from Sigma-Aldrich (St. Louis, MO, USA).

\subsection{Cell Lines and Cell Cultures}

HCC-38 and SKBR3 breast cancer cells were purchased from the Korean Cell Line Bank (KCLB, Seoul, Korea). HCC-38 and SKBR3 cells were maintained in the Roswell Park Memorial Institute (RPMI) 1640-medium with 10\% fetal bovine serum (FBS) and 1\% antibiotics. African green monkey kidney (Vero) and rat intestinal epithelial (RIE) cells (kindly provided by Dr. Seong Gyu Ko at Kyung Hee University, Seoul, Korea) were cultured in Dulbecco's modified Eagle medium (DMEM) supplemented with $10 \%$ FBS and $1 \%$ antibiotics at $37^{\circ} \mathrm{C}$ in a humidified atmosphere under $5 \% \mathrm{CO}_{2}$.

\subsection{Trypan Blue Assay}

Vero, RIE, HCC-38, and SKBR3 cells were seeded onto $60 \mathrm{~mm}$ plates for $24 \mathrm{~h}$. Cells were treated with L-AA $(50,100$, and $200 \mu \mathrm{M})$ for $48 \mathrm{~h}$ and then harvested using trypsin-EDTA. After the cells were harvested and suspended with phosphate-buffered saline (PBS), the cell suspension was mixed with $0.4 \%$ trypan blue solution (1:1) and incubated for $2 \mathrm{~min}$. Viable (trypan blue dye-excluding) and dead (trypan blue dye-including) cells were counted using a hemocytometer chamber under the microscope. 


\subsection{Colony Formation Assay}

HCC-38 and SKBR3 cells were seeded in 12-well plates at a density of 500 cells/well for $24 \mathrm{~h}$, and then treated with L-AA $(50,100$, and $200 \mu \mathrm{M})$. Every 3 days, the medium was replaced with fresh medium containing L-AA. After a 14 day treatment, the medium was discarded, and cell colonies were stained with crystal violet $(0.1 \%$ in $20 \%$ methanol) for $2 \mathrm{~h}$. After the colonies were washed with PBS, images were obtained to record the results. Crystal violet was extracted using 33\% acetic acid and quantified by measuring the absorbance at $570 \mathrm{~nm}$ using the microplate reader (Bio Tek Instrument Inc., Winooski, VT, USA).

\subsection{Reactive Oxygen Species (ROS) Measurement}

HCC-38 and SKBR3 cells were seeded onto $60 \mathrm{~mm}$ plates for $24 \mathrm{~h}$. The cells were treated with L-AA $(50,100$, and $200 \mu \mathrm{M})$ for $24 \mathrm{~h}$ and then treated with $10 \mu \mathrm{M}$ of $2^{\prime}-7^{\prime}$-dichlorodihydrofluorescein diacetate $\left(\mathrm{H}_{2}\right.$ DCF-DA, Molecular Probes, Eugene, OR, USA) for another $1 \mathrm{~h}$. The cells were harvested using trypsin-EDTA and centrifuged at $1000 \mathrm{rpm}$ for $5 \mathrm{~min}$ and analyzed by LSRFortessa flow cytometry.

\subsection{Apoptosis Analysis Assay}

HCC-38 and SKBR3 cells were seeded onto $60 \mathrm{~mm}$ plates for $24 \mathrm{~h}$ and treated with L-AA (50, 100, and $200 \mu \mathrm{M})$ for $48 \mathrm{~h}$. The cells were collected using trypsin-EDTA and centrifuged at $1000 \mathrm{rpm}$ for 5 min. After discarding the cell medium, cells were suspended in the binding buffer (BD Bioscience, San Jose, CA, USA) and stained with annexin V-fluorescein isothiocyanate (FITC) in the dark for 15 min, followed by the 7-aminoactinomycin D (7AAD) reaction for $15 \mathrm{~min}$. Annexin V and 7AAD-stained cells were detected using LSRFortessa flow cytometry (BD Bioscience, San Jose, CA, USA).

\subsection{Western Blotting}

HCC-38 and SKBR3 cells were seeded onto $60 \mathrm{~mm}$ plates and maintained for $24 \mathrm{~h}$. Cells were treated with L-AA $(200 \mu \mathrm{M})$ for various time points (0-6 or $24 \mathrm{~h})$ and harvested. Whole-cell lysates were prepared using the PRO-PREP protein extraction solution (iNtRON Biotechnology, Seoul, Korea). Protein concentrations were measured using the Bio-Rad Protein assay dye (Bio-Rad, Hercules, CA, USA) according to the manufacturer's instructions. An equal amount of protein of total lysate was subjected to $8 \%-12 \%$ sodium dodecyl sulfate-polyacrylamide gel electrophoresis and transferred onto polyvinylidene difluoride membranes. The membranes were blocked with $5 \%$ nonfat dry milk for $1 \mathrm{~h}$ and incubated with the relevant primary antibodies overnight at $4{ }^{\circ} \mathrm{C}$. The following are the primary antibodies: anti-caspase-12, C/EBP homologous protein (CHOP), and p62/SQSTM1 (sequestosome 1) antibodies were purchased from Abcam (Cambridge, MA, USA); anti-ATF4 (activating transcription factor 4), -elF2 $\alpha$ (eukaryotic initiation factor $2 \alpha$ ), -p-elF2 $\alpha$, and -p-IRE1 $\alpha$ were obtained from GeneTex Inc. (Irvine, CA, USA); anti- $\beta$-actin and -Bcl2 (B-cell lymphoma 2) were purchased from Santa Cruz Biotechnology (Santa, CA, USA); anti-p-PERK was purchased from MyBioSource (San Diego, CA, USA); anti-ATG3, -ATG7, -Beclin1, -Bip, - IRE1 $\alpha$, - LC3I/II, -PERK, -p-JNK, and -p-mTOR were obtained from Cell Signaling (Danvers, MA, USA). After washing, the membranes were incubated with horseradish peroxidase-labeled anti-rabbit IgG or -mouse IgG secondary antibodies at room temperature for $1 \mathrm{~h}$. Immunoreactive protein was exposed to X-ray films using West-zol ${ }^{\mathrm{TM}}$ Plus reagents (iNtRON Biotechnology, Seoul, Korea).

\subsection{Immunocytochemistry}

HCC-38 cells were seeded in 6-well plates with cover-glasses for $24 \mathrm{~h}$, and then treated with L-AA $(200 \mu \mathrm{M})$ for $6 \mathrm{~h}$. The cells were fixed with $4 \%$ paraformaldehyde for $10 \mathrm{~min}$ and washed with PBS three times. For permeabilization, the cells were incubated with $0.5 \%$ Triton X-100 for 7 min and washed. The cells were blocked with blocking buffer (10\% FBS and 1\% bovine serum albumin in $0.1 \%$ Tween-20 buffer) for $2 \mathrm{~h}$, and then stained with anti-p62/SQSTM1 primary antibody $(1 \mu \mathrm{g} / \mathrm{mL})$ and 
anti-Alexa Fluor-594 antibody (Invitrogen, Carlsbad, CA, USA 1:200) for $1 \mathrm{~h}$ at room temperature in the dark. After washing, the cells were mounted with 4',6-diamidino-2-phenylindole (DAPI)-contained VECTASHIELD mounting medium (Vector Laboratories, Burlingame, CA, USA). Images were acquired using a confocal microscope (FV10i, Olympus, Melville, NY, USA).

\subsection{Surface DR5 Expression Analysis}

HCC-38 cells were seeded onto $60 \mathrm{~mm}$ plates and treated with L-AA (50, 100, and $200 \mu \mathrm{M})$ for $24 \mathrm{~h}$. The cells were treated with trypsin-EDTA and centrifuged at $1000 \mathrm{rpm}$ for $5 \mathrm{~min}$. After washing with PBS, the cells were incubated with anti-death receptor 5 (DR5) primary antibody (Abcam, Cambridge, MA, USA, 1:100) in blocking buffer (2\% FBS in PBS) for $30 \mathrm{~min}$ on ice. The cells were washed and stained with anti-Alexa Fluor-488 secondary antibody (Invitrogen, Carlsbad, CA, 1:1000) or rabbit IgG monoclonal isotype control (Abcam, Cambridge, MA, USA) in the dark for $30 \mathrm{~min}$ on ice. DR5-positive cells were detected using LSRFortessa flow cytometry (BD Bioscience, San Jose, CA, USA).

\subsection{Transfection}

For $\mathrm{CHOP}$ or p62 transient knockdown, HCC-38 cells were seeded onto 6-well plates and transfected with siRNA (Bioneer, Daejeon, Korea) using the Lipofectamine reagent (Invitrogen, Carlsbad, CA, USA) according to the manufacturer's instruction. After the transfected cells were treated with L-AA $(200 \mu \mathrm{M})$ for $6 \mathrm{~h}$, western blotting, the trypan blue assay, colony formation assay, and immunocytochemical experiments were performed.

\subsection{Inhibitor Treatment}

HCC-38 cells were seeded and pre-treated with ER stress inhibitors $(4 \mu 8 \mathrm{C}$ : inositol-requiring endonuclease $1 \alpha(I R E 1 \alpha)$ inhibitor, $10 \mu \mathrm{M}$; SP600125: c-Jun N-terminal kinase (JNK) inhibitor, $1 \mu \mathrm{M}$; GSK2606414: PKR-like ER kinase (PERK) inhibitor, $10 \mu \mathrm{M}$; Salubrinal: elF2 $\alpha$ inhibitor, $10 \mu \mathrm{M}$ ) for $1 \mathrm{~h}$, and then treated with L-AA $(200 \mu \mathrm{M})$ for $6 \mathrm{~h}$. Thereafter, trypan blue assay, western blotting, and

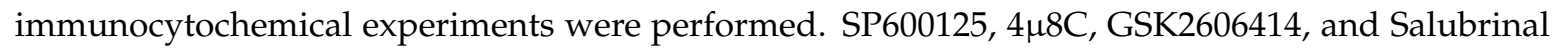
were purchased from Calbiochem (Cambridge, MA, USA).

\subsection{Statistical Analysis}

Results are shown as means \pm standard deviation (SD) from three independent experiments. A $p$-value less than 0.05 in the two-tailed Student's $t$-test was considered significant.

\section{Results}

\subsection{L-AA Induces Apoptosis of Breast Cancer Cells}

Breast cancer (HCC38 and SKBR3) and normal cells (Vero and RIE) were treated with L-AA at various concentrations $(50,100$, and $200 \mu \mathrm{M})$ for $48 \mathrm{~h}$. The viability of Vero and RIE cells was not affected, whereas the viability of breast cancer cells was reduced by L-AA treatment (Figure 1B). To confirm the long-term effect of L-AA treatment, we performed colony formation experiments. When HCC38 and SKBR3 were treated with L-AA for 14 days, L-AA decreased colony formation in a dose-dependent manner when compared with that in the control group (Figure 1C). To determine whether L-AA suppresses cell viability by inducing apoptosis, we performed annexin $\mathrm{V}$ and 7AAD staining. L-AA increased the percentage of annexin V-positive apoptotic cells (Figure 1D). These results suggest that L-AA suppresses the growth of breast cancer cells by inducing apoptotic cell death. 
A<smiles>O=C1OC(C(O)CO)C(O)=C1O</smiles>
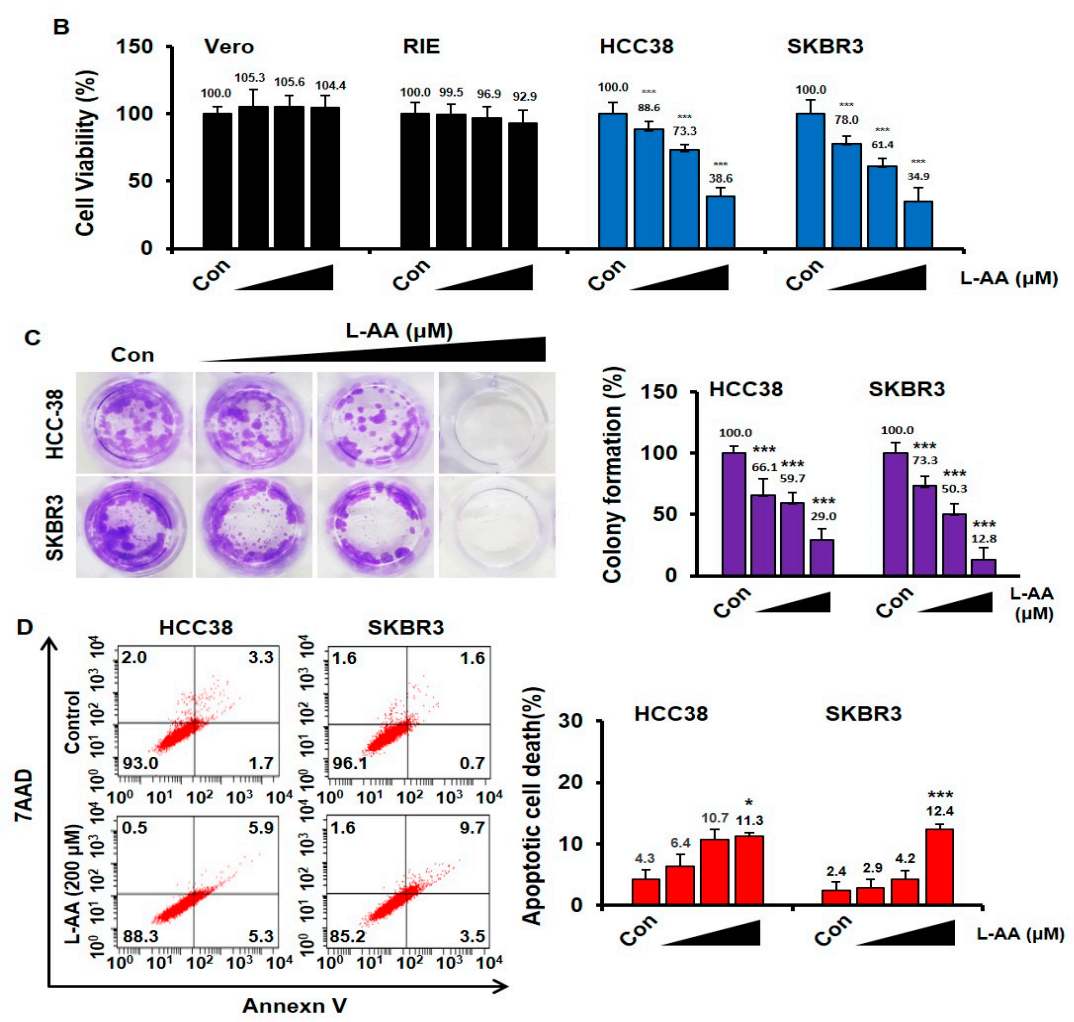

Figure 1. L-ascorbic acid (L-AA) inhibits breast cancer growth. (A) The chemical structure of L-AA. (B) Normal cells (Vero and rat intestinal epithelium (RIE)) and breast cancer cells (HCC38 and SKBR3) were treated with various concentrations of L-AA $(50,100$, and $200 \mu \mathrm{M})$ for $48 \mathrm{~h}$ and then stained with trypan blue. Viable and dead cells were counted. (C) Breast cancer cells were treated with L-AA (50, 100 , and $200 \mu \mathrm{M}$ ) every 3 days. After the 14 day treatment, cell colonies were stained with crystal violet. Crystal violet stained cells were extracted using 33\% acetic acid and quantified by measuring absorbance at $570 \mathrm{~nm}$ on the microplate reader. (D) Breast cancer cells were treated with L-AA (50, 100, and $200 \mu \mathrm{M}$ ) for $48 \mathrm{~h}$ and then stained with annexin V-FITC and 7AAD in the binding buffer at room temperature in the dark. Stained cells were detected by LSRFortessa flow cytometry. The graph shows the sum of annexin V-FITC alone-positive cells (early apoptotic cells) and annexin V-FITC and 7AAD double positive cells (late apoptotic cells) from whole stained cells. Data are shown as the mean of three independent experiments, and the error bars represent standard deviation (SD). ${ }^{*} p<0.05$ and $* * * p<0.001$ versus the control group.

\subsection{L-AA-Induced Apoptosis Is Not Correlated to the Intracellular ROS Generation}

Whether L-AA acts an anti-oxidant or pro-oxidant in cancer is still controversial [55-58]. We thus examined L-AA-induced ROS production. When HCC38 and SKBR3 breast cancer cells were treated with L-AA for $24 \mathrm{~h}$, L-AA decreased ROS production in a dose-dependent manner when compared with that in the control group (Figure 2A). To determine whether the decrease of ROS production by L-AA is required for L-AA-induced breast cancer cell death, HCC38 and SKBR3 breast cancer cells were treated with hydrogen peroxide $\left(\mathrm{H}_{2} \mathrm{O}_{2}\right)$, one of the pro-oxidants. The $\mathrm{H}_{2} \mathrm{O}_{2}$ treatment increased the ROS production when compared with that in the control group, while the $\mathrm{H}_{2} \mathrm{O}_{2}$ treatment in combination with L-AA attenuated the decrease of intracellular ROS levels by L-AA (Figure $2 \mathrm{~B}$ ). The $\mathrm{H}_{2} \mathrm{O}_{2}$ treatment 
in combination with L-AA increased apoptotic cell death and decreased cell viability when compared with L-AA treatment alone in breast cancer cells (Figure 2C,D). $\mathrm{H}_{2} \mathrm{O}_{2}$ treatment alone reduced the viability of breast cancer cells when compared with that in the control group, but it was not related to apoptosis (Figure 2C,D). These results indicate that L-AA-induced apoptosis of breast cancer cells was not correlated to the intracellular ROS generation.
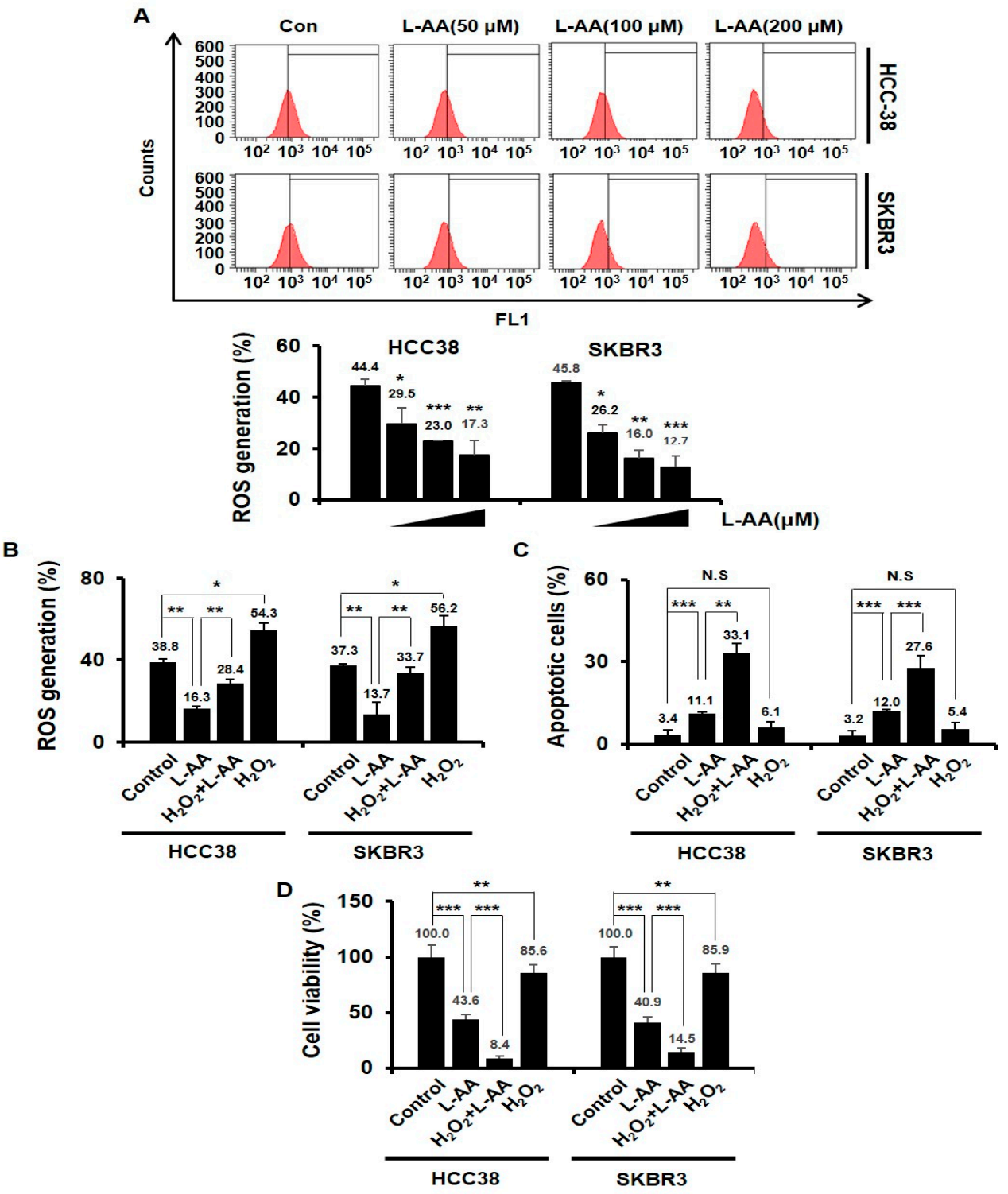

Figure 2. L-AA-induced apoptosis is not correlated to the intracellular reactive oxygen species (ROS) generation. (A) Breast cancer cells (HCC38 and SKBR3) were treated with various concentrations of L-AA $(50,100$, and $200 \mu \mathrm{M})$ for $24 \mathrm{~h}$ and then treated with $\mathrm{H}_{2}$ DCF-DA fluorescent dye for $1 \mathrm{~h}$ at $37^{\circ} \mathrm{C}$. ROS generation was measured by LSRFortessa flow cytometry. Graph shows the proportion of $\mathrm{H}_{2}$ DCF-DA-positive cells in the total cells. (B) Breast cancer cells were pre-treated with L-AA $(200 \mu \mathrm{M})$ for $1 \mathrm{~h}$, followed by exposure to $\mathrm{H}_{2} \mathrm{O}_{2}(10 \mu \mathrm{M})$ for $24 \mathrm{~h}$. ROS production was measured. (C,D) HCC38 and SKBR3 cells were pre-treated with L-AA $(200 \mu \mathrm{M})$ followed by exposure to $\mathrm{H}_{2} \mathrm{O}_{2}(10 \mu \mathrm{M})$ for $48 \mathrm{~h}$. (C) Stained with annexin V-FITC and 7AAD and analyzed by LSRFortessa flow cytometry. The graph shows the proportion of annexin V-FITC alone-positive cells (early apoptotic cells) and annexin V-FITC and 7AAD double positive cells (late apoptotic cells) in whole stained cells. (D) Trypan blue assay was performed. Data are shown as the mean of three independent experiments, and the error bars represent standard deviation (SD). ${ }^{*} p<0.05,{ }^{* *} p<0.01$, and ${ }^{* * *} p<0.001$ were considered statistically significant. 


\subsection{L-AA Induces Autophagosome Formation, While Increasing p62 Accumulation in the Nucleus}

To identify the mechanism by which L-AA induces apoptosis, we examined autophagy. Mammalian target of rapamycin $(m T O R)$ and Beclin1 are two important molecules involved in autophagy initiation and autophagosome formation [59]. Microtubule-associated protein 1A/1B-light chain 3 (LC3)I is combined with phosphatidylethanolamine (PE) to form LC3II via autophagy-related gene (ATG)-7 and -3 [60]. L-AA decreased mTOR phosphorylation in a time-dependent manner, while the level of Beclin1 was increased (Figure 3A). Furthermore, L-AA increased the expression of ATG-7 and ATG-3 (Figure 3A). L-AA also increased the expression of LC3II, which means that the number of autophagosomes increased (Figure 3B). Sequestosome 1 (p62/SQSTM1) is inserted into autophagosomes and degrades through the formation of an autolysosome fused with an autophagosome and lysosome. Thus, p62 has been known as an another autophagy marker degraded by autophagy induction [61]. However, we observed that p62 protein levels were increased by L-AA, although autophagic flux increased (Figure 3B).

In contrast, recent studies have reported that p62 expression can be upregulated by stress conditions, including oxidative stress, starvation, and accumulation of dysfunctional proteins [62-64]. Thus, we assessed whether L-AA could induce stress-mediated autophagy and p62 accumulation. To investigate the role of p62 on L-AA-inhibited cell viability, HCC38 cells were transfected with p62 siRNA. As shown in Figure 3C,D, following L-AA treatment, p62 silencing significantly increased cell viability when compared with the control siRNA-transfected cells. Recent reports suggest that DNA damage-induced by the inhibition of DNA repair requires p62 accumulation in the nucleus, which is associated with cell death $[65,66]$. As shown in Figure 3E, compared with control cells in which p62 is in the cytoplasm, the level of p62 increased in the nucleus of L-AA-treated cells. This indicates that L-AA induces stress-mediated autophagy and cell death via the accumulation of p62 in the nucleus. 


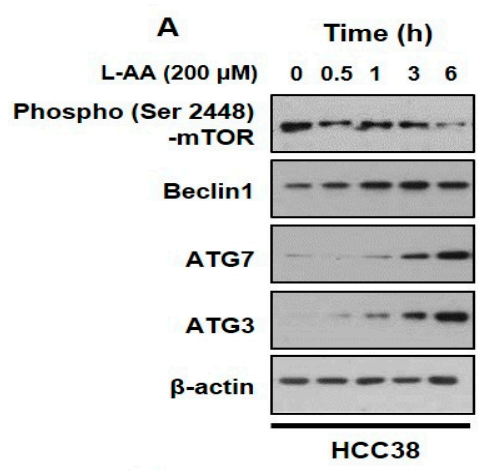

C
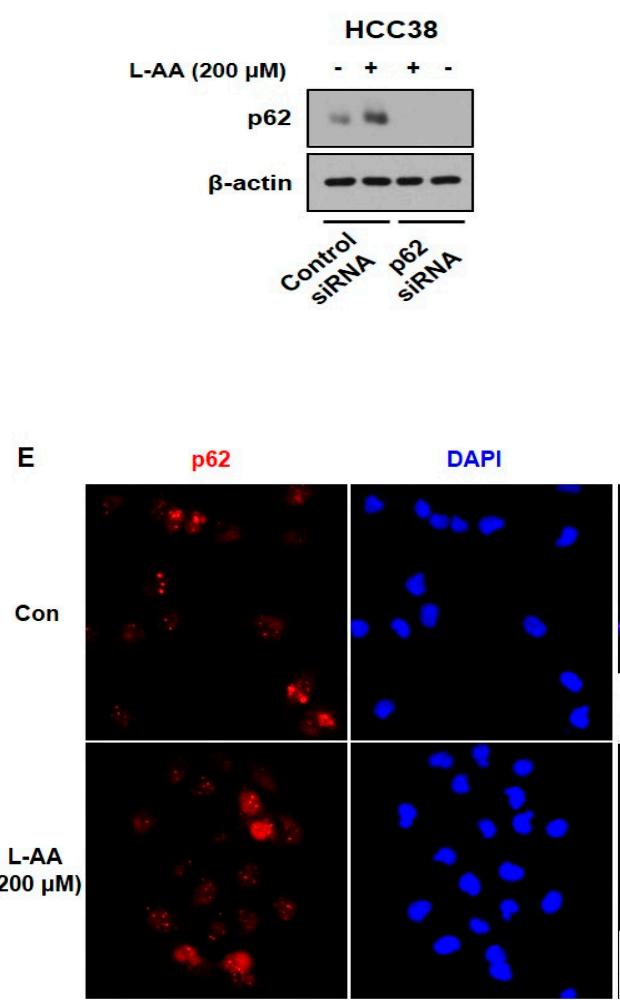
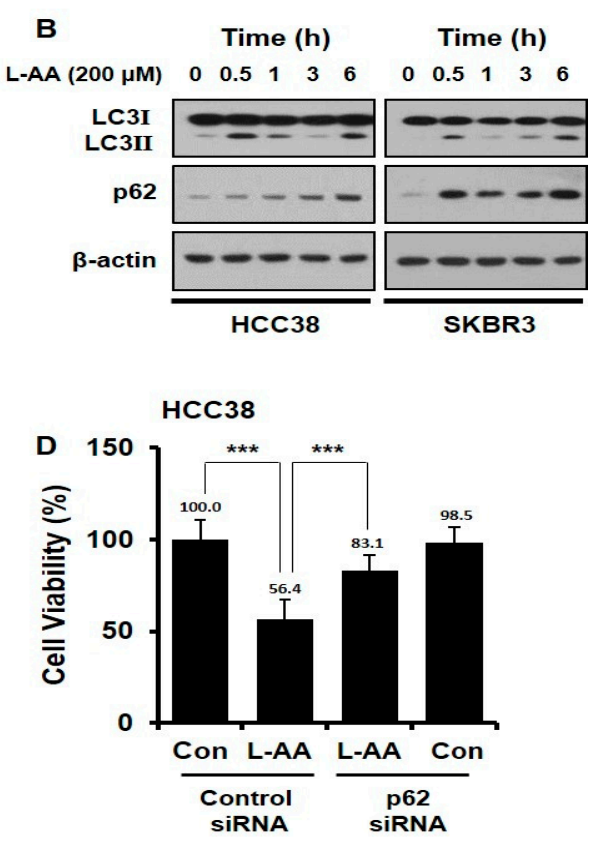

p62 / DAPI
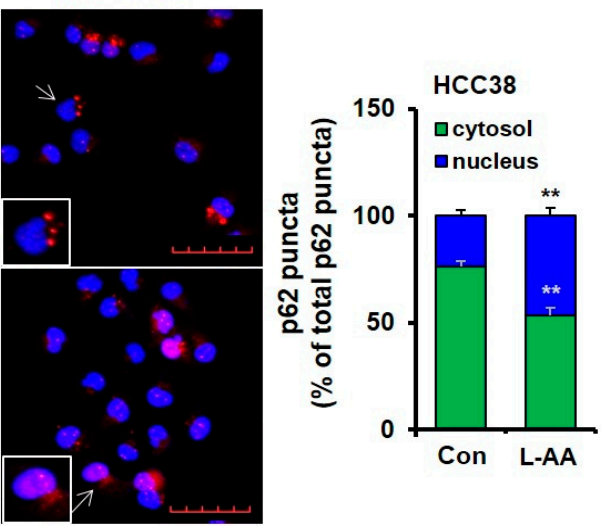

Figure 3. L-AA induces autophagosome formation, while L-AA increases p62 accumulation in the nucleus. (A,B) Breast cancer cells were treated with L-AA $(200 \mu \mathrm{M})$ for indicated hours $(0-6 \mathrm{~h})$ and then western blotting was performed with anti-p-mTOR, -Beclin1, -ATG7, -ATG3, -LC3I/II, and -p62. $\beta$-actin was used as the loading control. (C,D) HCC-38 cells were transfected with p62 siRNA and treated with $200 \mu \mathrm{M}$ of L-AA. (C) Western blotting was performed with anti-p62 and $\beta$-actin was used as the internal control. (D) Trypan blue assay was performed. (E) HCC-38 cells were treated with $200 \mu \mathrm{M}$ of L-AA for $6 \mathrm{~h}$. Cells were stained with anti-p62 $(1 \mu \mathrm{g} / \mathrm{mL})$ and -AlexaFluor-594 secondary antibody (1:200). Images were obtained using the FV10i confocal microscope, using the $40 \times$ objective; the scale bar indicates $50 \mu \mathrm{m}$. When the experiment was performed, three or more fields were obtained for each group, and p62 puncta were counted and averaged. This process was repeated three times, and the mean value of three experiments was statistically processed. Data are shown as the mean of three independent experiments, and the error bars represent standard deviation (SD). ${ }^{* *} p<0.01$ and *** $p<0.001$ were considered statistically significant.

\subsection{L-AA Induces ER Stress in Breast Cancer Cells}

A recent report indicates that ER stress is associated with the apoptotic pathway and p62 accumulation $[67,68]$. To investigate whether L-AA induces ER stress, we evaluated the expression of ER stress markers including C/EBP homologous protein $(\mathrm{CHOP})$ and cleaved caspase 12 . Breast cancer 
cells were treated with L-AA and western blotting was performed to confirm the CHOP and cleaved caspase 12 expression. L-AA enhanced CHOP and cleaved caspase 12 levels in HCC38 and SKBR3 cells (Figure 4A). Next, we examined the effect of L-AA on ER stress-related pathways regulating CHOP, including inositol-requiring endonuclease 1 (IRE1 $\alpha$ ) and PKR-like ER kinase (PERK) signaling. The two pathways including IRE-c-Jun N-terminal kinase (JNK) and PERK-eukaryotic initiation factor 2 (elF2)- $\alpha$ are crucial for the transmission of ER-stress signals to CHOP in cancer [69,70]. L-AA induced the phosphorylation of IRE1 $\alpha$ and JNK levels (Figure 4B). Moreover, L-AA increased binding immunoglobulin protein (Bip), p-PERK, p-elF2 $\alpha$, and activating transcription factor 4 (ATF4), indicating the activation of the PERK signaling pathway (Figure $4 \mathrm{C}$ ). As a transcription factor, CHOP regulates the expression of a variety of apoptosis-related genes, including B-cell lymphoma 2 (Bcl2) and DR5 [71,72]. L-AA decreased Bcl2 levels and increased membrane DR5 expression (Figure 4D,E). Therefore, the results indicate that L-AA induces ER stress in breast cancer cells.

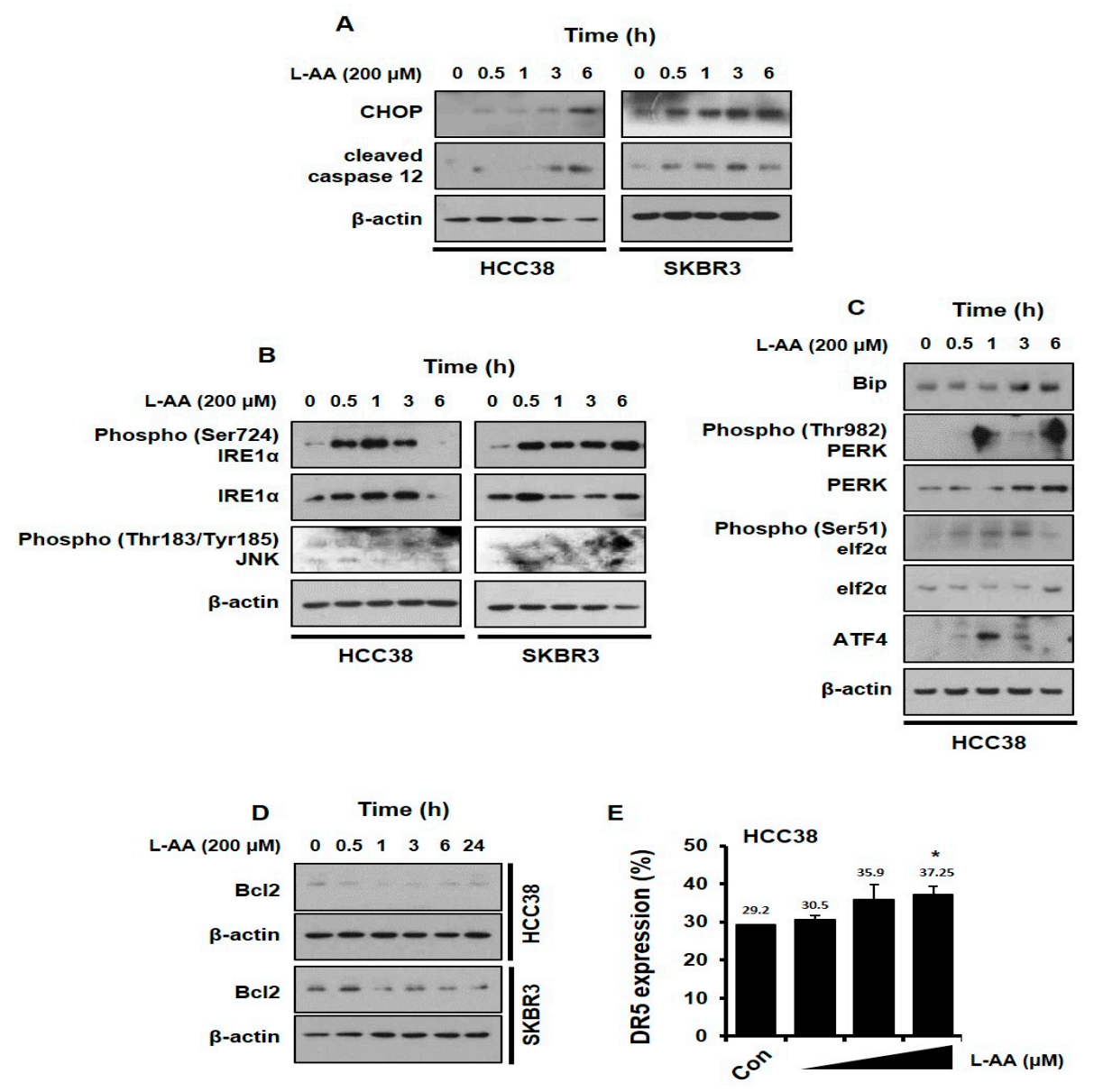

Figure 4. L-AA increases endoplasmic reticulum (ER) stress in breast cancer cells. (A,D) HCC-38 or SKBR3 cells were treated with $200 \mu \mathrm{M}$ of L-AA for indicated hours, and then western blotting was performed. $\beta$-actin was used as the loading control. (A) Expression levels of C/EBP homologous protein $(\mathrm{CHOP})$ and cleaved caspase 12. (B) Protein levels involved in ER stress associated inositol-requiring endonuclease 1 (IRE1) signaling pathway. (C) Protein levels involved in ER stress-related PKR-like ER kinase (PERK) signaling pathway. (D) B-cell lymphoma 2 (Bcl2) expression levels (E) HCC-38 cells were treated with $200 \mu \mathrm{M}$ of L-AA for $24 \mathrm{~h}$ and stained with anti-DR5 (death receptor 5) primary antibody (1:100) and -AlexaFluor-488 secondary antibody (1:1000). DR5-positive cells were detected by LSRFortessa flow cytometry. Data are shown as the mean of three independent experiments, and the error bars represent standard deviation (SD). ${ }^{*} p<0.05$ versus the control group. 


\subsection{L-AA Inhibits Breast Cancer Growth via IRE1/JNK/CHOP Signaling}

To confirm the role of the IRE-JNK and PERK-elF2 $\alpha$ pathways in L-AA-induced cell death, experiments using ER stress inhibitors were performed. We observed that GSK2606414 (PERK inhibitor) or Salubrinal (elF2 $\alpha$ inhibitor) in combination with L-AA did not restore growth inhibition

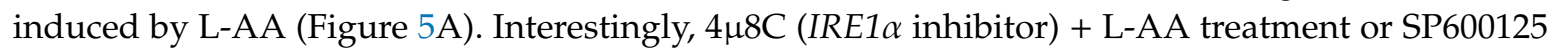
(JNK inhibitor) + L-AA treatment increased cell viability when compared with L-AA treatment alone (Figure 5A). None of the inhibitors affected cell viability (Figure 5A). In addition, L-AA increased the cell viability and colony formation in CHOP-knockdown cells when compared with those in control siRNA-treated cells (Figure 5B-D). However, cytotoxicity was observed only in CHOP-knockdown cells (Figure 5C,D). Thus, our data suggest that L-AA inhibited the growth of breast cancer cells via activation of the IRE signaling pathway.
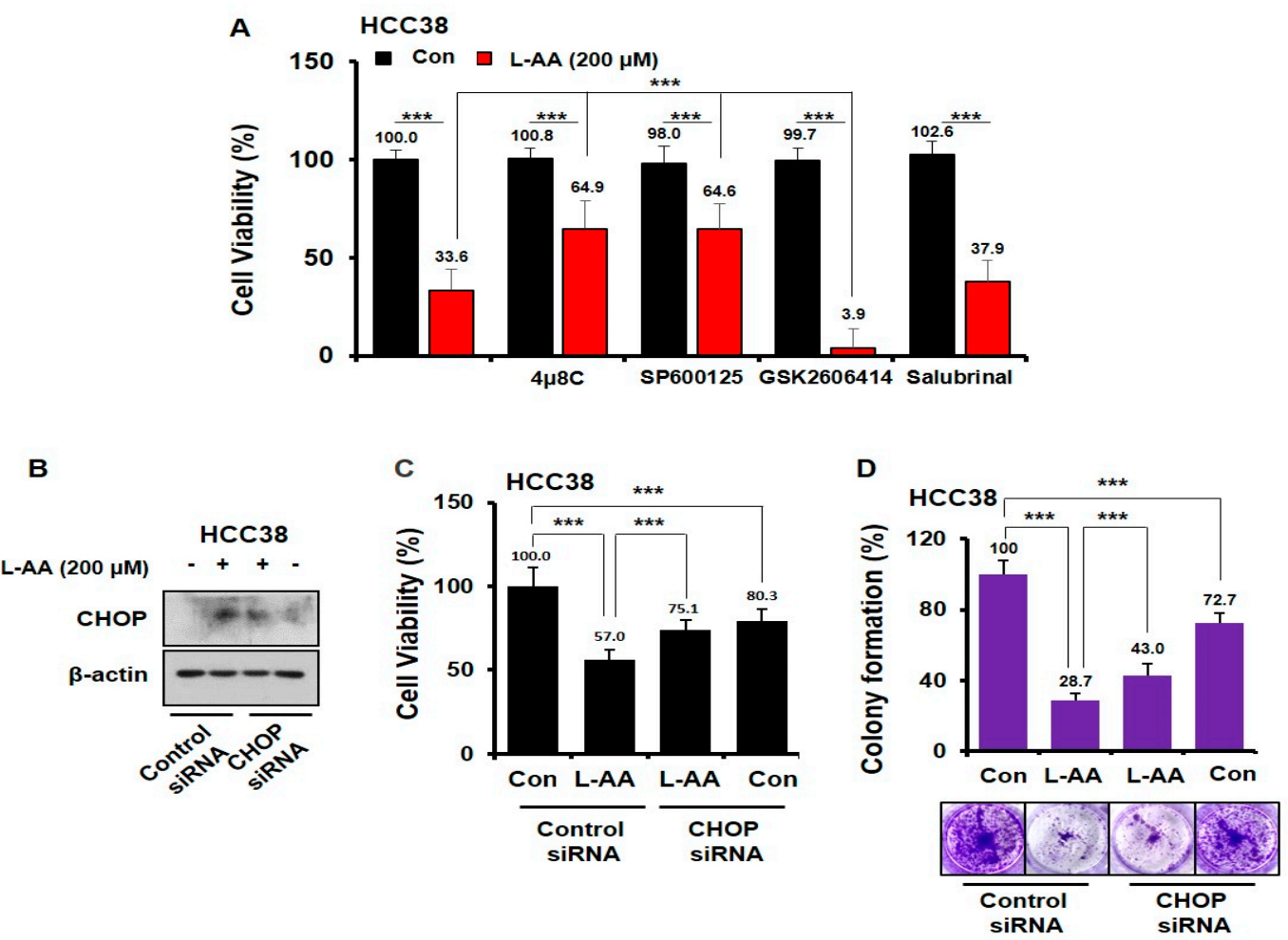

Figure 5. L-AA enhances IRE1-c-Jun N-terminal kinase (JNK)-CHOP-mediated cell death. (A) HCC-38 cells were pre-treated with ER stress inhibitors (10 $\mu \mathrm{M}$ of 4 $\mu 8 \mathrm{C}, 1 \mu \mathrm{M}$ of SP600125, $10 \mu \mathrm{M}$ of GSK2606414, and $10 \mu \mathrm{M}$ of Salubrinal) for $1 \mathrm{~h}$, and then treated with L-AA $(200 \mu \mathrm{M})$ for $48 \mathrm{~h}$. Cell viability was measured using the trypan blue assay. (B,D) HCC-38 cells were transfected with CHOP siRNA. (B) CHOP siRNA-transfected cells were treated with $200 \mu \mathrm{M}$ of L-AA for $6 \mathrm{~h}$ and then western blotting was performed (C) CHOP siRNA-transfected cells were treated with $200 \mu \mathrm{M}$ of L-AA for $48 \mathrm{~h}$, followed by the trypan blue assay (D) CHOP siRNA-transfected cells were treated with $200 \mu \mathrm{M}$ of L-AA for 10 days, followed by the colony formation assay. Data are shown as the mean of three independent experiments, and the error bars represent standard deviation (SD). ${ }^{* * *} p<0.001$ was considered statistically significant.

\subsection{L-AA-Induced IRE Signaling Causes p62 Accumulation in the Nucleus}

To further confirm whether the activation of the IRE/JNK/CHOP signal regulates L-AA-induced p62 expression and accumulation in the nucleus, inhibitor and knockdown experiments were performed.

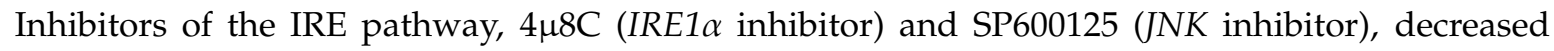
L-AA-induced p62 expression levels. The treatment with $4 \mu 8 \mathrm{C}$ or SP600125 did not affect the p62 expression levels (Figure 6A). In HCC38 cells, knockdown of CHOP attenuated L-AA-increased p62 
levels when compared with the control siRNA + L-AA group (Figure 6B). Next, confocal experiments were performed to confirm the localization of p62 using combination treatment with L-AA and IRE signal inhibitors. L-AA alone increased the nuclear level of p62, while co-treatment with L-AA and inhibitors (4 $48 \mathrm{C}$ and SP600125) attenuated L-AA-induced nuclear accumulation of p62 (Figure 6C). Our findings suggest that inhibition of the IRE pathway suppresses the nuclear accumulation of p62 induced by L-AA in breast cancer cells.
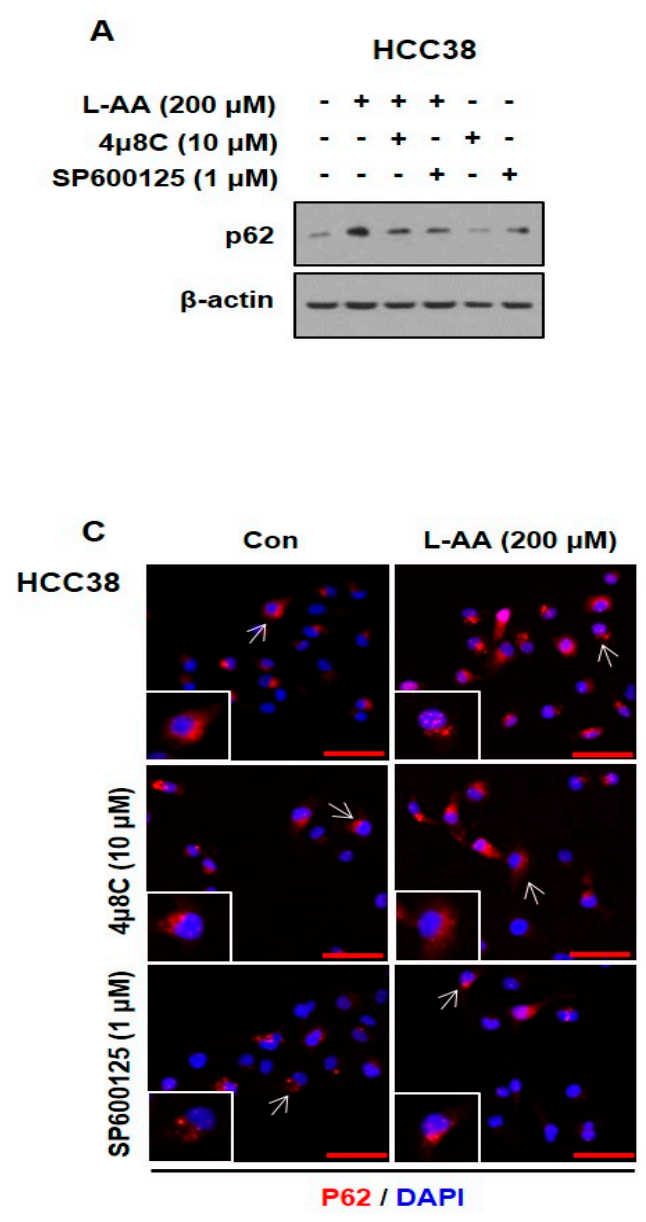

B
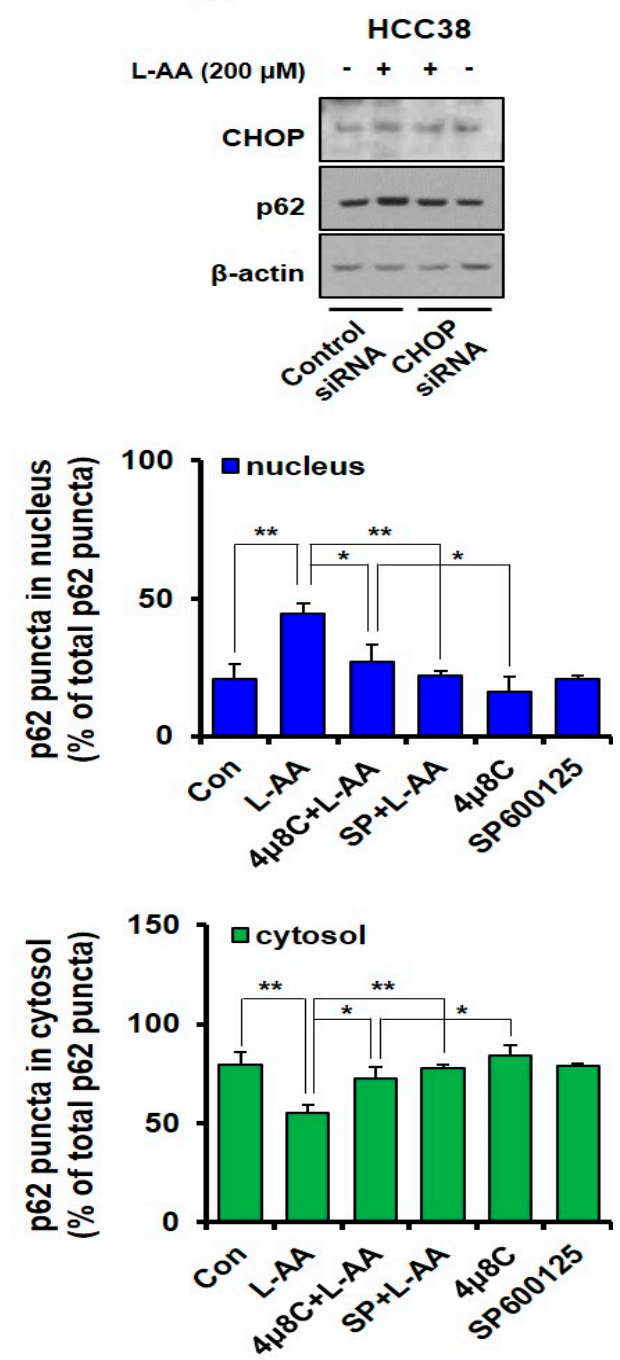

Figure 6. L-AA-induced IRE1-JNK-CHOP activation causes p62 accumulation in the nucleus. (A) HCC-38 cells were pre-treated with IRE1 signaling pathway inhibitors such as $4 \mu 8 \mathrm{C}(10 \mu \mathrm{M})$ and SP600125 $(1 \mu \mathrm{M})$ for $1 \mathrm{~h}$ and treated with L-AA $(200 \mu \mathrm{M})$ for $6 \mathrm{~h}$. Western blotting was performed with anti-p62, and $\beta$-actin was used as the internal control. (B) HCC-38 cells were transfected with CHOP siRNA, treated with L-AA $(200 \mu \mathrm{M})$ for $6 \mathrm{~h}$, and then western blotting was performed. (C) HCC-38 cells were pre-treated with the IRE1 signal pathway inhibitors, such as $4 \mu 8 \mathrm{C}(10 \mu \mathrm{M})$ and SP600125 $(1 \mu \mathrm{M})$, and treated with L-AA $(200 \mu \mathrm{M})$ for $6 \mathrm{~h}$. Cells were stained with anti-p62 $(1 \mu \mathrm{g} / \mathrm{mL})$ and -AlexaFluor-594 secondary antibody (1:200). Images were obtained using the FV10i confocal microscope, using the $40 \times$ objective; the scale bar indicates $50 \mu \mathrm{m}$. Following the experiment, three or more fields were obtained for each group, and p62 puncta were counted and averaged. This process was repeated three times, and the mean value of three experiments was statistically processed. The following graph shows the ratio of p62 puncta expressed in the cytosol and nucleus, based on $100 \%$ of total p62 puncta. Data are shown as the mean of three independent experiments, and the error bars represent standard deviation (SD). ${ }^{*} p<0.05$ and ${ }^{* *} p<0.01$ were considered statistically significant. 


\section{Discussion}

Although the anticancer effect of L-AA has been demonstrated in various experiments, it is still controversial to administer L-AA in patients with cancer due to a lack of mechanism-based studies. In the present study, we demonstrated that L-AA induced apoptotic death and ER stress in breast cancer cells. Furthermore, we observed that L-AA increased the nuclear level of p62 via ER stress-mediated IRE-JNK-CHOP signaling pathways.

L-AA acts as an anti-oxidant or as pro-oxidant in cancer, so it is still controversial [55-58]. Unlike some previous studies that ascorbate is oxidized in the medium and consequently ROS is generated, our study showed that L-AA decreased intracellular ROS levels (Figure 2A). Furthermore, when treated with $\mathrm{H}_{2} \mathrm{O}_{2}$ acting as a pro-oxidant, it was observed that the decrease of ROS by L-AA was not correlated with apoptosis induction of breast cancer cells by L-AA (Figure 2C,D). The oxidative state of L-AA is crucial to the anticancer effects of L-AA in many studies, but our study showed that the anticancer effect of L-AA in breast cancer cells was independent of the oxidative state of L-AA. During carcinogenesis, the accumulation of aberrant proteins in the ER by chromosomal rearrangements, hypoxia, and environment factors induces ER stress [73-75]. Cells minimize ER stress by activating the UPR system to protect themselves and maintain homeostasis during ER stress [43,44]. The UPR system is mediated by IRE, PERK, and ATF6, which are located on the ER membrane and activated by ER stress stimulation [76,77]. UPR increases the expression of chaperone proteins, improving the function of ER in terms of protein synthesis and folding. Additionally, UPR decreases the amount of protein that enters the ER or increases the degradation of unfolded proteins in the ER, thereby reducing the ER burden and consequently suppressing ER stress [78,79]. Nevertheless, if the ER stress is not reduced and the ER fails to restore its function, apoptosis is activated to remove damaged cells [79]. Therefore, the mechanism of ER stress-mediated apoptosis could be utilized as a new therapeutic target for cancer research. Various compounds regulating this mechanism are being studied and validated $[47,80]$. Transcription of the CHOP gene is extremely crucial in ER stress-mediated apoptosis, which is activated by IRE1, PERK, and ATF6 [81,82]. ER stress-mediated apoptosis is less induced in CHOP-deficient cells, whereas overexpression of the $C H O P$ gene promotes apoptosis $[83,84]$. Furthermore, $C H O P$ also reduces $B c l 2$ and upregulates DR5, followed by the induction of the apoptosis pathway [62].

ER stress-mediated apoptosis can also be induced by IRE1-mediated JNK activity and caspase 12, an ER stress-specific caspase located on the outer layer of the ER [79]. In this study, L-AA induced the activation of two important signaling pathways in ER stress, IRE1-JNK and PERK-elF2 $\alpha-A T F 4$ (Figure 4B,C). However, the PERK-elF2 $\alpha-A T F 4$ pathway was not associated with the anticancer effect of L-AA, and the inhibition of L-AA-mediated cell viability was only improved by IRE1-JNK signaling (Figure 5A). In addition, L-AA increased the expression of ER stress-mediated apoptosis markers, cleaved caspase 12 and $C H O P$, and the increased CHOP was crucial for L-AA-inhibited cell growth (Figures 4A and 5B-D). Moreover, the expression of Bcl2 and DR5, which are important for apoptosis induction controlled by CHOP transcriptional activity, was regulated by L-AA (Figure $4 \mathrm{D}, \mathrm{E}$ ). CHOP is known to be a potential target for drug development in cancer [85]. Reportedly, resveratrol [86], Polyphenon $\mathrm{E}^{\circledR}$ [87], gartanin [88], garcinol [89], and Clinacanthus nutans [90] exhibit anticancer effects via $C H O P$ regulation.

ER stress induces processes related to cell survival and death, such as autophagy [91-93]. Autophagy is an important process for maintaining homeostasis in normal cells and it is a cellular degradation pathway for the removal of damaged or superfluous proteins and organelles [94]. During autophagy, cytoplasmic materials are sequestered by the autophagosome, a double-membrane structure, and fused with the lysosome for degradation [95]. Autophagy is valuable as a therapeutic target for cancer treatment since it has been reported that it regulates initiation, growth, survival, malignancy, and metastasis of cancer [96,97]. mTOR is a major negative regulator of autophagy and is important in regulating the activity of kinases, including UNC-51-like kinase 1 (ULK1) [98,99]. Beclin1 induces autophagy by forming the Beclin1-class III phosphatidylinositol 3-kinase (Vps34) complex. Additionally, the SH3 domain of Beclin1 binds to anti-apoptotic Bcl2 to regulate apoptosis [100]. 
In our study, L-AA increased the initiation of autophagy and autophagosome formation, which are regulated by the activation of $m$ TOR and the increase of Beclin1, ATG-7, and -3 (Figure 3A). As a result, the conversion of LC3II was enhanced by L-AA (Figure 3B). As a chaperone of ubiquitinated proteins of the autophagosome, p62/SQSTM1, binds to LC3 of the autophagosome and is itself degraded by autophagy [101].

However, we unexpectedly observed a significant increase in the p62 protein levels in breast cancer cells treated with L-AA (Figure 3B). Additionally, knockdown of p62 expression attenuated L-AA-inhibited cell viability (Figure 3D). Consistent with our results, several studies have shown that autophagic cell death through p62 increasingly inhibits cancer growth in hepatocellular carcinoma [68,102], leukemia [103], breast cancer [104], and pleural mesothelioma cells [105]. Moreover, p62 upregulation has been observed when ER stress-mediated apoptosis occurred, which is related to the ER stress-activated IRE1-JNK signaling pathway [68,105]. Our study also confirmed that L-AA increased p62 levels through IRE-JNK-CHOP pathway (Figure 6A,B). Furthermore, recent studies have shown that ER stress increases the accumulation of p62 by blocking autophagosome-lysosome fusion and inhibiting lysosomal functions [106]. p62 is a nucleocytoplasmic shuttling protein, the nuclear roles of which remains largely unknown. Recently, p62 accumulation in the nucleus has been reported to induce DNA damage-associated cell death [65,66]. In addition, low nuclear p62 expression is related to a high histologic grade, as well as poor overall and disease-specific survival in oral squamous cell carcinoma [107]. In this study, L-AA increased nuclear p62, which correlated with the ER stress-mediated IRE-JNK signaling pathway (Figures 3E and 6C).

Breast cancer is a heterogeneous disease and is classified into different subtypes depending on the presence or absence of hormone receptors such as estrogen receptor $(E s R)$, progesterone receptor $(P R)$, and human epidermal growth factor receptor 2 (HER2). Unlike other cancers, hormone therapy and HER2-targeted therapy are possible depending on the characteristics and subtype of the patients with breast cancer [108,109]. Because heterogeneity of breast cancer subtypes is the most common cause of therapy failure, it is important to proceed with research or development of therapeutic agents considering breast cancer subtypes [110]. On the other hand, the sensitivity of L-AA in breast cancer cells is known to correlate with the expression of sodium-dependent vitamin C transporter-2 (SVCT-2), which transports L-AA to cells [58]. SVCT-2 expression is revealed to be higher in EsR/PR-negative than in EsR/PR-positive breast cancer patient tissues [58]. The SKBR3 cell line used in our study was reported to have high $S V C T-2$ expression and high sensitivity to L-AA treatment as an ER/PR-negative cell line [58]. HCC38 cells are also known as EsR/PR-negative breast cancer cell line [111], but the expression of SVCT-2 in HCC38 cells has not been reported. The amount of ascorbate in cancer cells which is dependent on the expression of SVCT-2, is crucial to the efficacy of L-AA in clinical and in vivo studies. To further verify the efficacy of L-AA in breast cancer, we will investigate the expression and regulatory mechanisms of SVCT-2 that determine the sensitivity of L-AA and conduct in vivo studies using xenograft animal model in further research.

\section{Conclusions}

In conclusion, we observed that L-AA induces p62 accumulation in the nucleus through the ER stress-mediated IRE1-JNK-CHOP pathway, thereby promoting cell death. Our study provides scientific evidence regarding the applicability of L-AA treatment in breast cancer patients.

Author Contributions: Y.K.C. and H.-K.K. conceived and designed the experiments; Y.K.C. and J.-I.K. performed the experiments; Y.K.C., J.-I.K., and H.-K.K. analyzed the data; Y.K.C., Y.W.K., and D.R.C. writing-original draft; Y.K.C. and H.-K.K. writing-review and editing; H.-K.K., S.H., Y.R.K., J.J., J.W.H., Y.S.K., and E.-S.Y. contributed reagents/materials/analysis tools. All authors have read and agreed to the published version of the manuscript.

Funding: This work was supported by the research grant from Jeju National University Hospital development fund in 2016.

Conflicts of Interest: The authors declare no conflict of interest. 


\section{References}

1. Ausman, L.M. Criteria and Recommendations for Vitamin C Intake. Nutr. Rev. 2009, 57, 222-224. [CrossRef]

2. Van Gorkom, G.N.; Lookermans, E.L.; Van Elssen, C.H.; Bos, G.M. The Effect of Vitamin C (Ascorbic Acid) in the Treatment of Patients with Cancer: A Systematic Review. Nutrients 2019, 11, 977. [CrossRef]

3. Padayatty, S.J.; Katz, A.; Wang, Y.; Eck, P.; Kwon, O.; Lee, J.-H.; Chen, S.; Corpe, C.; Dutta, A.; Dutta, S.K.; et al. Vitamin $C$ as an antioxidant: Evaluation of its role in disease prevention. J. Am. Coll. Nutr. 2003, 22, 18-35. [CrossRef]

4. Pullar, J.M.; Carr, A.C.; Vissers, M.C.M. The Roles of Vitamin C in Skin Health. Nutrients 2017, 9, 866. [CrossRef]

5. Abbaspour, N.; Hurrell, R.; Kelishadi, R. Review on iron and its importance for human health. J. Res. Med. Sci. 2014, 19, 164-174.

6. Harrison, F.E.; May, J.M. Vitamin C function in the brain: Vital role of the ascorbate transporter SVCT2. Free. Radic. Biol. Med. 2009, 46, 719-730. [CrossRef]

7. Chakraborthy, A.; Ramani, P.; Sherlin, H.; Premkumar, P.; Natesan, A. Antioxidant and pro-oxidant activity of Vitamin C in oral environment. Indian J. Dent. Res. 2014, 25, 499. [CrossRef]

8. Chun, O.K.; Chun, O.K. Vitamin C and Heart Health: A Review Based on Findings from Epidemiologic Studies. Int. J. Mol. Sci. 2016, 17, 1328. [CrossRef]

9. He, M.; Qiao, Y.; Zhang, Z.; Wu, Z.; Liu, D.; Liao, Z.; Yin, D.; He, M. Dual action of vitamin C in iron supplement therapeutics for iron deficiency anemia: Prevention of liver damage induced by iron overload. Food Funct. 2018, 9, 5390-5401. [CrossRef]

10. Balbi, M.E.; Tonin, F.S.; Mendes, A.M.; Borba, H.; Wiens, A.; Fernandez-Llimos, F.; Pontarolo, R. Antioxidant effects of vitamins in type 2 diabetes: A meta-analysis of randomized controlled trials. Diabetol. Metab. Syndr. 2018, 10, 18. [CrossRef]

11. Johnson, E.J.; Rasmussen, H.M. Nutrients for the aging eye. Clin. Interv. Aging 2013, 8, 741-748. [CrossRef]

12. Monacelli, F.; Acquarone, E.; Giannotti, C.; Borghi, R.; Nencioni, A. Vitamin C, Aging and Alzheimer's Disease. Nutrients 2017, 9, 670. [CrossRef] [PubMed]

13. Hemilä, H. Vitamin C and Infections. Nutrients 2017, 9, 339. [CrossRef] [PubMed]

14. Hahm, E.; Jin, N.-H.; Kang, J.S.; Kim, Y.-I.; Hong, S.-W.; Lee, S.K.; Na Kim, H.; Jung, D.J.; Kim, J.E.; Shin, N.H.; et al. The molecular mechanisms of vitamin C on cell cycle regulation in B16F10 murine melanoma. J. Cell. Biochem. 2007, 102, 1002-1010. [CrossRef] [PubMed]

15. Gan, L.; Camarena, V.; Mustafi, S.; Wang, G. Vitamin C Inhibits Triple-Negative Breast Cancer Metastasis by Affecting the Expression of YAP1 and Synaptopodin 2. Nutrients 2019, 11, 2997. [CrossRef]

16. Lim, J.Y.; Kim, D.; Kim, B.R.; Jun, J.S.; Yeom, J.S.; Park, J.S.; Seo, J.-H.; Park, C.H.; Woo, H.O.; Youn, H.; et al. Vitamin C induces apoptosis in AGS cells via production of ROS of mitochondria. Oncol. Lett. 2016, 12, 4270-4276. [CrossRef]

17. Yun, J.; Mullarky, E.; Lu, C.; Bosch, K.N.; Kavalier, A.; Rivera, K.; Roper, J.; Chio, I.I.C.; Giannopoulou, E.G.; Rago, C.; et al. Vitamin C selectively kills KRAS and BRAF mutant colorectal cancer cells by targeting GAPDH. Science 2015, 350, 1391-1396. [CrossRef]

18. Du, J.; Martin, S.M.; Levine, M.; Wagner, B.A.; Buettner, G.R.; Wang, S.-H.; Taghiyev, A.F.; Du, C.; Knudson, C.M.; Cullen, J.J. Mechanisms of Ascorbate-Induced Cytotoxicity in Pancreatic Cancer. Clin. Cancer Res. 2010, 16, 509-520. [CrossRef]

19. Roomi, M.W.; House, D.; Eckert-Maksić, M.; Maksić, Z.B.; Tsao, C.S. Growth suppression of malignant leukemia cell line in vitro by ascorbic acid (vitamin C) and its derivatives. Cancer Lett. 1998, 122, 93-99. [CrossRef]

20. Mehdi, W.A.; Zainulabdeen, J.A.; Mehde, A.A. Investigation of the antioxidant status in multiple myeloma patients: Effects of therapy. Asian Pac. J. Cancer Prev. 2013, 14, 3663-3667. [CrossRef]

21. Huijskens, M.J.; Wodzig, W.K.; Walczak, M.; Germeraad, W.T.V.; Bos, G.M. Ascorbic acid serum levels are reduced in patients with hematological malignancies. Results Immunol. 2016, 6, 8-10. [CrossRef] [PubMed]

22. Blaszczak, W.; Barczak, W.; Masternak, J.; Kopczyński, P.; Zhitkovich, A.; Rubiś, B. Vitamin C as a Modulator of the Response to Cancer Therapy. Molecules 2019, 24, 453. [CrossRef] [PubMed] 
23. Mahdavi, R.; Faramarzi, E.; Seyedrezazadeh, E.; Mohammadzadeh, M.; Pourmoghaddam, M. Evaluation of Oxidative Stress, Antioxidant Status and Serum Vitamin C Levels in Cancer Patients. Biol. Trace Element Res. 2009, 130, 1. [CrossRef] [PubMed]

24. Emri, S.; Kilickap, S.; Kadilar, C.; Halil, M.G.; Akay, H.; Besler, T.; Besler, H.T. Serum Levels of Alpha-Tocopherol, Vitamin C, Beta-Carotene, and Retinol in Malignant Pleural Mesothelioma. Asian Pac. J. Cancer Prev. 2012, 13, 3025-3029. [CrossRef]

25. Harrison, F.E. A Critical Review of Vitamin C for the Prevention of Age-Related Cognitive Decline and Alzheimer's Disease. J. Alzheimer's Dis. 2012, 29, 711-726. [CrossRef]

26. Douglas, R.M.; Hemila, H.; D'Souza, R.; Chalker, E.B.; Treacy, B. Vitamin C for preventing and treating the common cold. Cochrane Database Syst. Rev. 2004, 18. [CrossRef]

27. Levine, M.; Espey, M.G.; Chen, Q. Losing and finding a way at C: New promise for pharmacologic ascorbate in cancer treatment. Free. Radic. Biol. Med. 2009, 47, 27-29. [CrossRef]

28. Cameron, E.; Pauling, L. Supplemental ascorbate in the supportive treatment of cancer: Prolongation of survival times in terminal human cancer. Proc. Natl. Acad. Sci. USA 1976, 73, 3685-3689. [CrossRef]

29. Cameron, E.; Pauling, L. Supplemental ascorbate in the supportive treatment of cancer: Reevaluation of prolongation of survival times in terminal human cancer. Proc. Natl. Acad. Sci. USA 1978, 75, 4538-4542. [CrossRef]

30. Gandini, S.; Merzenich, H.; Robertson, C.; Boyle, P. Meta-analysis of studies on breast cancer risk and diet. Eur. J. Cancer 2000, 36, 636-646. [CrossRef]

31. Cameron, E.; Campbell, A. The orthomolecular treatment of cancer II. Clinical trial of high-dose ascorbic acid supplements in advanced human cancer. Chem. Interact. 1974, 9, 285-315. [CrossRef]

32. Creagan, E.T.; Moertel, C.G.; O’Fallon, J.R.; Schutt, A.J.; O'Connell, M.J.; Rubin, J.; Frytak, S. Failure of High-Dose Vitamin C (Ascorbic Acid) Therapy to Benefit Patients with Advanced Cancer. N. Engl. J. Med. 1979, 301, 687-690. [CrossRef]

33. Moertel, C.G.; O'Connell, M.J.; Ames, M.M.; Fleming, T.R.; Creagan, E.T.; Rubin, J. High-Dose Vitamin C versus Placebo in the Treatment of Patients with Advanced Cancer Who Have Had No Prior Chemotherapy. N. Engl. J. Med. 1985, 312, 137-141. [CrossRef]

34. Michels, K.B.; Holmberg, L.; Bergkvist, L.; Ljung, H.; Bruce, A.; Wolk, A. Dietary antioxidant vitamins, retinol, and breast cancer incidence in a cohort of Swedish women. Int. J. Cancer 2001, 91, 563-567. [CrossRef]

35. Zeng, L.-H.; Wang, Q.-M.; Feng, L.-Y.; Ke, Y.-D.; Xu, Q.-Z.; Wei, A.-Y.; Zhang, C.; Ying, R.-B. High-dose vitamin $C$ suppresses the invasion and metastasis of breast cancer cells via inhibiting epithelial-mesenchymal transition. OncoTargets Ther. 2019, 12, 7405-7413. [CrossRef] [PubMed]

36. Padayatty, S.J.; Sun, H.; Wang, Y.; Riordan, H.D.; Hewitt, S.; Katz, A.; Wesley, R.A.; Levine, M. Vitamin C pharmacokinetics: Implications for oral and intravenous use. Ann. Intern. Med. 2004, 140, 533-537. [CrossRef] [PubMed]

37. Hoffer, L.J.; Levine, M.; Assouline, S.; Melnychuk, D.; Padayatty, S.J.; Rosadiuk, K.; Rousseau, C.; Robitaille, L.; Miller, W.H. Phase I clinical trial of i.v. ascorbic acid in advanced malignancy. Ann. Oncol. 2008, 19, 1969-1974. [CrossRef] [PubMed]

38. Verrax, J.; Calderon, P.B. Pharmacologic concentrations of ascorbate are achieved by parenteral administration and exhibit antitumoral effects. Free. Radic. Biol. Med. 2009, 47, 32-40. [CrossRef]

39. Lin, J.H.; Walter, P.; Yen, T.B. Endoplasmic reticulum stress in disease pathogenesis. Annu. Rev. Pathol. Mech. Dis. 2008, 3, 399-425. [CrossRef]

40. Yoshida, H. ER stress and diseases. FEBS J. 2007, 274, 630-658. [CrossRef]

41. Kaneko, M.; Imaizumi, K.; Saito, A.; Kanemoto, S.; Asada, R.; Matsuhisa, K.; Ohtake, Y. ER Stress and Disease: Toward Prevention and Treatment. Biol. Pharm. Bull. 2017, 40, 1337-1343. [CrossRef]

42. Oakes, S.A.; Papa, F.R. The role of endoplasmic reticulum stress in human pathology. Annu. Rev. Pathol. Mech. Dis. 2014, 10, 173-194. [CrossRef]

43. Schröder, M.; Kaufman, R.J. ER stress and the unfolded protein response. Mutat. Res. Mol. Mech. Mutagen. 2005, 569, 29-63. [CrossRef]

44. Maurel, M.; McGrath, E.; Mnich, K.; Healy, S.; Chevet, E.; Samali, A. Controlling the unfolded protein response-mediated life and death decisions in cancer. Semin. Cancer Biol. 2015, 33, 57-66. [CrossRef] 
45. Pike, L.R.G.; Singleton, D.C.; Buffa, F.M.; Abramczyk, O.; Phadwal, K.; Li, J.; Simon, A.K.; Murray, J.; Harris, A.L. Transcriptional up-regulation of ULK1 by ATF4 contributes to cancer cell survival. Biochem. J. 2012, 449, 389-400. [CrossRef]

46. Kim, I.; Xu, W.; Reed, J.C. Cell death and endoplasmic reticulum stress: Disease relevance and therapeutic opportunities. Nat. Rev. Drug Discov. 2008, 7, 1013-1030. [CrossRef]

47. Limonta, P.; Moretti, R.M.; Marzagalli, M.; Fontana, F.; Raimondi, M.; Marelli, M.M. Role of Endoplasmic Reticulum Stress in the Anticancer Activity of Natural Compounds. Int. J. Mol. Sci. 2019, 20, 961. [CrossRef]

48. Siegel, R.L.; Miller, K.D.; Jemal, A. Cancer statistics, 2019. CA 2019, 69, 7-34. [CrossRef]

49. Greenlee, H.; Kwan, M.L.; Kushi, L.H.; Song, J.; Castillo, A.; Weltzien, E.; Quesenberry, C.P.; Caan, B.J. Antioxidant supplement use after breast cancer diagnosis and mortality in the Life After Cancer Epidemiology (LACE) cohort. Cancer 2011, 118, 2048-2058. [CrossRef]

50. Nechuta, S.; Lu, W.; Chen, Z.; Zheng, Y.; Gu, K.; Cai, H.; Zheng, W.; Shu, X.-O. Vitamin supplement use during breast cancer treatment and survival: A prospective cohort study. Cancer Epidemiol. Biomark. Prev. 2010, 20, 262-271. [CrossRef]

51. Poole, E.; Shu, X.; Caan, B.J.; Flatt, S.W.; Holmes, M.D.; Lu, W.; Kwan, M.L.; Nechuta, S.J.; Pierce, J.P.; Chen, W.Y. Post-diagnosis supplement use and breast cancer prognosis in the After Breast Cancer Pooling Project. Breast Cancer Res. Treat. 2013, 139, 529-537. [CrossRef]

52. Hutchinson, J.; Lentjes, M.; Greenwood, D.C.; Burley, V.; Cade, J.E.; Cleghorn, C.L.; Threapleton, D.E.; Key, T.J.; Cairns, B.; Keogh, R.H.; et al. Vitamin C intake from diary recordings and risk of breast cancer in the UK Dietary Cohort Consortium. Eur. J. Clin. Nutr. 2011, 66, 561-568. [CrossRef]

53. Hu, F.; Wu, Z.; Li, G.; Teng, C.; Liu, Y.; Wang, F.; Zhao, Y.; Pang, D. The plasma level of retinol, vitamins A, $\mathrm{C}$ and $\alpha$-tocopherol could reduce breast cancer risk? A meta-analysis and meta-regression. J. Cancer Rese. Clin. Oncol. 2014, 141, 601-614. [CrossRef]

54. Harris, H.R.; Orsini, N.; Wolk, A. Vitamin C and survival among women with breast cancer: A Meta-analysis. Eur. J. Cancer 2014, 50, 1223-1231. [CrossRef]

55. Fukumura, H.; Sato, M.; Kezuka, K.; Sato, I.; Feng, X.; Okumura, S.; Fujita, T.; Yokoyama, U.; Eguchi, H.; Ishikawa, Y.; et al. Effect of ascorbic acid on reactive oxygen species production in chemotherapy and hyperthermia in prostate cancer cells. J. Physiol. Sci. 2012, 62, 251-257. [CrossRef]

56. Cárcamo, J.M.; Pedraza, A.; Bórquez-Ojeda, O.; Zhang, B.; Sánchez, R.; Golde, D.W. Vitamin C Is a Kinase Inhibitor: Dehydroascorbic Acid Inhibits IкB $\alpha$ Kinase $\beta$. Mol. Cell. Biol. 2004, 24, 6645-6652. [CrossRef]

57. Chen, Q.; Espey, M.G.; Sun, A.; Pooput, C.; Kirk, K.L.; Krishna, M.C.; Khosh, D.B.; Drisko, J.; Levine, M. Pharmacologic doses of ascorbate act as a prooxidant and decrease growth of aggressive tumor xenografts in mice. Proc. Natl. Acad. Sci. USA 2008, 105, 11105-11109. [CrossRef]

58. Hong, S.-W.; Lee, S.-H.; Moon, J.-H.; Hwang, J.J.; Kim, D.E.; Ko, E.; Kim, H.-S.; Cho, I.J.; Kang, J.-S.; Kim, J.-E.; et al. SVCT-2 in breast cancer acts as an indicator for L-ascorbate treatment. Oncogene 2012, 32, 1508-1517. [CrossRef]

59. Shi, B.; Ma, M.; Zheng, Y.; Pan, Y.; Lin, X. mTOR and Beclin1: Two key autophagy-related molecules and their roles in myocardial ischemia/reperfusion injury. J. Cell. Physiol. 2019, 234, 12562-12568. [CrossRef]

60. Frudd, K.; Burgoyne, T.; Burgoyne, J. Oxidation of Atg3 and Atg7 mediates inhibition of autophagy. Nat. Commun. 2018, 9, 95. [CrossRef]

61. Stolz, A.; Ernst, A.; Dikic, I. Cargo recognition and trafficking in selective autophagy. Nat. Cell Biol. 2014, 16, 495-501. [CrossRef]

62. Jain, A.; Lamark, T.; Sjøttem, E.; Larsen, K.B.; Awuh, J.A.; Øvervatn, A.; McMahon, M.; Hayes, J.; Johansen, T. p62/SQSTM1 Is a Target Gene for Transcription Factor NRF2 and Creates a Positive Feedback Loop by Inducing Antioxidant Response Element-driven Gene Transcription. J. Biol. Chem. 2010, 285, 22576-22591. [CrossRef]

63. Sahani, M.H.; Itakura, E.; Mizushima, N. Expression of the autophagy substrate SQSTM1/p62 is restored during prolonged starvation depending on transcriptional upregulation and autophagy-derived amino acids. Autophagy 2014, 10, 431-441. [CrossRef]

64. B'Chir, W.; Maurin, A.-C.; Carraro, V.; Averous, J.; Jousse, C.; Muranishi, Y.; Parry, L.; Stepien, G.; Fafournoux, P.; Bruhat, A. The eIF2 $\alpha /$ ATF4 pathway is essential for stress-induced autophagy gene expression. Nucleic Acids Res. 2013, 41, 7683-7699. [CrossRef] 
65. Wang, Y.; Zhang, N.; Zhang, L.; Li, R.; Fu, W.; Ma, K.; Li, X.; Wang, L.; Wang, J.; Zhang, H.; et al. Autophagy Regulates Chromatin Ubiquitination in DNA Damage Response through Elimination of SQSTM1/p. Mol. Cell 2016, 63, 34-48. [CrossRef]

66. Wang, L.; Howell, M.E.A.; Sparks-Wallace, A.; Hawkins, C.; Nicksic, C.A.; Kohne, C.; Hall, K.H.; Moorman, J.; Yao, Z.Q.; Ning, S. p62-mediated Selective autophagy endows virus-transformed cells with insusceptibility to DNA damage under oxidative stress. PLOS Pathog. 2019, 15, e1007541. [CrossRef]

67. Fernandez, A.; Ordóñez, R.; Reiter, R.J.; González-Gallego, J.; Mauriz, J.L. Melatonin and endoplasmic reticulum stress: Relation to autophagy and apoptosis. J. Pineal Res. 2015, 59, 292-307. [CrossRef]

68. Go, D.-H.; Lee, Y.G.; Lee, D.-H.; Kim, J.-A.; Jo, I.-H.; Han, Y.S.; Jo, Y.H.; Kim, K.-Y.; Seo, Y.-K.; Moon, J.-H.; et al. 3-Decylcatechol induces autophagy-mediated cell death through the IRE1 $\alpha / \mathrm{JNK} / \mathrm{p} 62$ in hepatocellular carcinoma cells. Oncotarget 2017, 8, 58790-58800. [CrossRef]

69. Li, Y.; Guo, Y.; Tang, J.; Jiang, J.; Chen, Z. New insights into the roles of CHOP-induced apoptosis in ER stress. Acta Biochim. Biophys. Sin. 2015, 47, 146-147. [CrossRef]

70. Rozpędek, W.; Pytel, D.; Mucha, B.; Leszczyńska, H.; Diehl, J.; Majsterek, I. The role of the PERK/eIF2 $\alpha /$ ATF4/CHOP signaling pathway in tumor progression during Endoplasmic Reticulum stress. Curr. Mol. Med. 2016, 16, 533-544. [CrossRef]

71. Hu, H.; Tian, M.; Ding, C.; Yu, S. The C/EBP Homologous Protein (CHOP) Transcription Factor Functions in Endoplasmic Reticulum Stress-Induced Apoptosis and Microbial Infection. Front. Immunol. 2019, 9, 3083. [CrossRef]

72. Chen, P.; Hu, T.; Liang, Y.; Li, P.; Chen, X.; Zhang, J.; Ma, Y.; Hao, Q.; Wang, J.; Zhang, P.; et al. Neddylation Inhibition Activates the Extrinsic Apoptosis Pathway through ATF4-CHOP-DR5 Axis in Human Esophageal Cancer Cells. Clin. Cancer Res. 2016, 22, 4145-4157. [CrossRef]

73. Khan, M.; Nomura, T.; Chiba, T.; Tanaka, K.; Yoshida, H.; Mori, K.; Ishii, S. The Fusion Oncoprotein PML-RAR $\alpha$ Induces Endoplasmic Reticulum (ER)-associated Degradation of N-CoR and ER Stress. J. Biol. Chem. 2003, 279, 11814-11824. [CrossRef]

74. Feldman, U.E.; Chauhan, V.; Koong, A. The Unfolded Protein Response: A Novel Component of the Hypoxic Stress Response in Tumors. Mol. Cancer Res. 2005, 3, 597-605. [CrossRef]

75. Koshikawa, N.; Maejima, C.; Miyazaki, K.; Nakagawara, A.; Takenaga, K. Hypoxia selects for high-metastatic Lewis lung carcinoma cells overexpressing Mcl-1 and exhibiting reduced apoptotic potential in solid tumors. Oncogene 2005, 25, 917-928. [CrossRef]

76. Hetz, C.; Martinon, F.; Rodriguez, D.; Glimcher, L.H. The Unfolded Protein Response: Integrating Stress Signals Through the Stress Sensor IRE1 $\alpha$. Physiol. Rev. 2011, 91, 1219-1243. [CrossRef]

77. Ron, D.; Walter, P. Signal integration in the endoplasmic reticulum unfolded protein response. Nat. Rev. Mol. Cell Biol. 2007, 8, 519-529. [CrossRef]

78. Boyce, M.; Yuan, J. Cellular response to endoplasmic reticulum stress: A matter of life or death. Cell Death Differ. 2006, 13, 363-373. [CrossRef]

79. Hetz, C. The unfolded protein response: Controlling cell fate decisions under ER stress and beyond. Nat. Rev. Mol. Cell Biol. 2012, 13, 89-102. [CrossRef]

80. Corazzari, M.; Lovat, P.E.; Armstrong, J.; Fimia, G.M.; Hill, D.S.; Birch-Machin, M.; Redfern, C.; Piacentini, M. Targeting homeostatic mechanisms of endoplasmic reticulum stress to increase susceptibility of cancer cells to fenretinide-induced apoptosis: The role of stress proteins ERdj5 and ERp57. Br. J. Cancer 2007, 96, 1062-1071. [CrossRef]

81. Oyadomari, S.; Mori, M. Roles of CHOP/GADD153 in endoplasmic reticulum stress. Cell Death Differ. 2003, 11, 381-389. [CrossRef]

82. Li, Y.; Guo, Y.; Tang, J.; Jiang, J.-L.; Chen, Z. New insights into the roles of CHOP-induced apoptosis in ER stress. Acta Biochim. Biophys. Sin. 2014, 46, 629-640. [CrossRef]

83. McCullough, K.D.; Martindale, J.L.; Klotz, L.-O.; Aw, T.-Y.; Holbrook, N.J. Gadd153 Sensitizes Cells to Endoplasmic Reticulum Stress by Down-Regulating Bcl2 and Perturbing the Cellular Redox State. Mol. Cell. Biol. 2001, 21, 1249-1259. [CrossRef]

84. Oyadomari, S.; Takeda, K.; Takiguchi, M.; Gotoh, T.; Matsumoto, M.; Wada, I.; Akira, S.; Araki, E.; Mori, M. Nitric oxide-induced apoptosis in pancreatic cells is mediated by the endoplasmic reticulum stress pathway. Proc. Natl. Acad. Sci. USA 2001, 98, 10845-10850. [CrossRef] 
85. Scaiewicz, V.; Nahmias, A.; Chung, R.T.; Mueller, T.; Tirosh, B.; Shibolet, O. CCAAT/Enhancer-Binding Protein Homologous (CHOP) Protein Promotes Carcinogenesis in the DEN-Induced Hepatocellular Carcinoma Model. PLOS ONE 2013, 8, e81065. [CrossRef]

86. Wang, F.-M.; Galson, D.L.; Roodman, G.D.; Ouyang, H. Resveratrol triggers the pro-apoptotic endoplasmic reticulum stress response and represses pro-survival XBP1 signaling in human multiple myeloma cells. Exp. Hematol. 2011, 39, 999-1006. [CrossRef]

87. Rizzi, F.; Naponelli, V.; Silva, A.; Modernelli, A.; Ramazzina, I.; Bonacini, M.; Tardito, S.; Gatti, R.; Uggeri, J.;

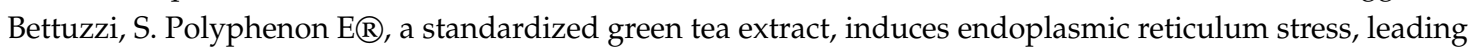
to death of immortalized PNT1a cells by anoikis and tumorigenic PC3 by necroptosis. Carcinogenesis 2013, 35, 828-839. [CrossRef]

88. Li, G.; Petiwala, S.M.; Yan, M.; Won, J.H.; Petukhov, P.A.; Johnson, J.J. Gartanin, an isoprenylated xanthone from the mangosteen fruit (Garcinia mangostana), is an androgen receptor degradation enhancer. Mol. Nutr. Food Res. 2016, 60, 1458-1469. [CrossRef]

89. Cheng, A.-C.; Tsai, M.-L.; Liu, C.-M.; Lee, M.-F.; Nagabhushanam, K.; Ho, C.-T.; Pan, M.-H. Garcinol inhibits cell growth in hepatocellular carcinoma Hep3B cells through induction of ROS-dependent apoptosis. Food Funct. 2010, 1, 301. [CrossRef]

90. Lu, M.-C.; Li, T.-Y.; Hsieh, Y.-C.; Hsieh, P.-C.; Chu, Y.-L. Chemical evaluation and cytotoxic mechanism investigation of Clinacanthus nutans extract in lymphoma SUP-T1 cells. Environ. Toxicol. 2018, 33, 1229-1236. [CrossRef]

91. Demirtas, L.; Guclu, A.; Erdur, F.M.; Akbas, E.M.; Ozcicek, A.; Onk, D.; Turkmen, K. Apoptosis, autophagy \& endoplasmic reticulum stress in diabetes mellitus. Indian J. Med Res. 2016, 144, 515-524.

92. Gan, P.-P.; Zhou, Y.-Y.; Zhong, M.-Z.; Peng, Y.; Li, L.; Li, J.-H. Endoplasmic Reticulum Stress Promotes Autophagy and Apoptosis and Reduces Chemotherapy Resistance in Mutant p53 Lung Cancer Cells. Cell. Physiol. Biochem. 2017, 44, 133-151. [CrossRef]

93. Heath-Engel, H.M.; Chang, N.C.; Shore, G.C. The endoplasmic reticulum in apoptosis and autophagy: Role of the BCL-2 protein family. Oncogene 2008, 27, 6419-6433. [CrossRef]

94. Kawabata, T.; Yoshimori, T. Beyond starvation: An update on the autophagic machinery and its functions. J. Mol. Cell. Cardiol. 2016, 95, 2-10. [CrossRef]

95. Nakamura, S.; Yoshimori, T. New insights into autophagosome-lysosome fusion. J. Cell Sci. 2017, 130, 1209-1216. [CrossRef]

96. Byun, S.; Lee, E.; Lee, Y. Therapeutic Implications of Autophagy Inducers in Immunological Disorders, Infection, and Cancer. Int. J. Mol. Sci. 2017, 18, 1959. [CrossRef]

97. Lin, S.-R.; Fu, Y.-S.; Tsai, M.-J.; Cheng, H.; Weng, C.-F. Natural Compounds from Herbs that can Potentially Execute as Autophagy Inducers for Cancer Therapy. Int. J. Mol. Sci. 2017, 18, 1412. [CrossRef]

98. Egan, D.F.; Shackelford, D.B.; Mihaylova, M.M.; Gelino, S.R.; Kohnz, R.A.; Mair, W.; Vasquez, D.S.; Joshi, A.; Gwinn, D.M.; Taylor, R.; et al. Phosphorylation of ULK1 (hATG1) by AMP-Activated Protein Kinase Connects Energy Sensing to Mitophagy. Science 2010, 331, 456-461. [CrossRef]

99. Cicchini, M.; Karantza, V.; Xia, B. Molecular pathways: Autophagy in cancer-a matter of timing and context. Clin. Cancer Res. 2014, 21, 498-504. [CrossRef]

100. Kang, R.; Zeh, H.J.; Lotze, M.T.; Tang, D. The Beclin 1 network regulates autophagy and apoptosis. Cell Death Differ. 2011, 18,571-580. [CrossRef]

101. Johansen, T.; Lamark, T. Selective autophagy mediated by autophagic adapter proteins. Autophagy 2011, 7, 279-296. [CrossRef] [PubMed]

102. Vegliante, R.; Desideri, E.; Di Leo, L.; Ciriolo, M.R. Dehydroepiandrosterone triggers autophagic cell death in human hepatoma cell line HepG2 via JNK-mediated p62/SQSTM1 expression. Carcinogenesis 2016, 37, 233-244. [CrossRef] [PubMed]

103. Puissant, A.; Robert, G.; Fenouille, N.; Luciano, F.; Cassuto, J.-P.; Raynaud, S.; Auberger, P. Resveratrol Promotes Autophagic Cell Death in Chronic Myelogenous Leukemia Cells via JNK-Mediated p62/SQSTM1 Expression and AMPK Activation. Cancer Res. 2010, 70, 1042-1052. [CrossRef] [PubMed]

104. Choi, Y.K.; Cho, S.-G.; Choi, Y.-J.; Yun, Y.J.; Lee, K.M.; Lee, K.; Yoo, H.-H.; Shin, Y.C.; Ko, S.-G. SH003 suppresses breast cancer growth by accumulating p62 in autolysosomes. Oncotarget 2016, 8, 88386-88400. [CrossRef] 
105. Lee, J.; Sohn, E.J.; Yoon, S.; Won, G.; Kim, C.G.; Jung, J.H.; Kim, S.-H. Activation of JNK and IRE1 is critically involved in tanshinone I-induced p62 dependent autophagy in malignant pleural mesothelioma cells: Implication of p62 UBA domain. Oncotarget 2017, 8, 25032-25045. [CrossRef]

106. Nakashima, A.; Cheng, S.; Kusabiraki, T.; Motomura, K.; Aoki, A.; Ushijima, A.; Ono, Y.; Tsuda, S.; Shima, T.; Yoshino, O.; et al. Endoplasmic reticulum stress disrupts lysosomal homeostasis and induces blockade of autophagic flux in human trophoblasts. Sci. Rep. 2019, 9, 11466. [CrossRef]

107. Liu, J.-L.; Chen, F.-F.; Lung, J.; Lo, C.-H.; Lee, F.-H.; Lu, Y.-C.; Hung, C.-H. Prognostic significance of p62/SQSTM1 subcellular localization and LC3B in oral squamous cell carcinoma. Br. J. Cancer 2014, 111, 944-954. [CrossRef]

108. Turashvili, G.; Brogi, E. Tumor Heterogeneity in Breast Cancer. Front. Med. 2017, 4, 227. [CrossRef]

109. Cardoso, F.; Senkus, E.; Fallowfield, L.; Costa, A.; Castiglione, M.; ESMO Guidelines Working Group. Locally recurrent or metastatic breast cancer: ESMO Clinical Practice Guidelines for diagnosis, treatment and follow-up. Ann. Oncol. 2010, 21, v15-v19. [CrossRef]

110. Jeibouei, S.; Akbari, M.E.; Kalbasi, A.; Aref, A.R.; Ajoudanian, M.; Rezvani, A.; Zali, H. Personalized medicine in breast cancer: Pharmacogenomics approaches. Pharmacogenomics Pers. Med. 2019, 12, 59-73. [CrossRef]

111. Hardin, C.; Pommier, R.; Calhoun, K.; Müller, P.; Jackson, T.; Pommier, S. A New Hormonal Therapy for Estrogen Receptor-Negative Breast Cancer. World J. Surg. 2007, 31, 1041-1046. [CrossRef]

(C) 2020 by the authors. Licensee MDPI, Basel, Switzerland. This article is an open access article distributed under the terms and conditions of the Creative Commons Attribution (CC BY) license (http://creativecommons.org/licenses/by/4.0/). 